\title{
Genetic Diversity of Merozoite Surface Protein 2 (MSP2) Plasmodium falciparum Clinical Isolate in Wamena General Hospital
}

\author{
DIRK Y.P. RUNTUBOI ${ }^{1}$, ROSYE H.R. TANJUNG ${ }^{1, *}$, YULIUS SARUNGU ${ }^{2}$, MEIDY J. IMBIRI ${ }^{3}$, \\ IRMA A. RESMOL ${ }^{3}$, IGN. JOKO SUYONO ${ }^{1}$ \\ ${ }^{1}$ Department of Biology, Faculty of Mathematics and natural Sciences, Cenderawasih University, Papua, Indonesia \\ ${ }^{2}$ Department of Public Health, Cenderawasih University, Papua, Indonesia \\ ${ }^{3}$ Institute of Health Science Jayapura, Indonesia
}

Received: January 7, 2020 - Accepted: August 21, 2020

(c) 2020 Department of Biology, Cenderawasih University

\begin{abstract}
The genetic diversity of typical clinical isolated Plasmodium falciparum in the malaria population varies greatly, especially at the location where malaria disease were recorded at high incidence rate. MSP2 is known as glycoprotein expressed on the surface of merozoites, which is an antigenic protein and has a potential to act as vaccine candidate for malaria. The MSP2 gene has two main allelic groups called FC27 and 3D7/IC. Block 3 from MSP2 gene is the most polymorphic to describe the diversity of parasite populations. The $P$. falciparum parasite population is often characterized by wide genetic diversity in areas of high transmission intensity. Therefore, the study on P. falciparum diversity is useful to describe the level of malaria transmission. The study of genetic diversity focused on clinical isolated species at Wamena General Hospital was aimed to determine the presence of the MSP2 gene, variety of MSP2 gene allele and the dominant frequency of the MSP2 gene allele. This research has been carried out from March 2018 to February 2019 using a cross sectional approach. The research sample was taken and prepared from Wamena Regional Hospital and followed by the analyzing of DNA isolation, PCR, electrophoresis of the research samples was done at the genetic science laboratory in Jakarta, Indonesia. The samples studied were patients who met the inclusion criteria, namely a single P. falciparum infection with an asexual parasite density $>1000$ parasites $/ \mu \mathrm{l}$ or $>3+(1-10 \mathrm{P} / \mathrm{Lp})$, and were agreed to become respondents by signing an informed consent. A total of 26 clinical isolates of $P$. falciparum were isolated with the MSP2 gene distribution on the FC27 allele with the highest as many as 25 samples (96.2\%), 22 samples (84.6\%) of the 3D7 / IC allele while the mixture of the two alleles was 22 samples (84.6\%). From a total of 26 samples, there were samples with the male gender category counted for $77.3 \%$ and female $41 \%$. The results of the identification of clinical isolated P. falciparum at Wamena Hospital with a total of 26 samples were found in productive age, between 15-34 years with a single allele $(95.8 \%$ ), while 23 cases and mix (both alleles $87.5 \%$ ) about 21 cases, meanwhile in cases of before-productive age, in which ages were 12 and 14 years of age with a single allele $100 \%$ (FC27) 2 cases and 50\% (3D7/IC) found to be 1 case, The mixture of the two alleles is $50 \%$ was only 1 case and there was no sample at non-productive age observed.
\end{abstract}

Key words: Malaria; MSP-2; P. falciparum; Wamena

\section{INTRODUCTION}

Wamena is the capital of Jayawijaya Regency

* Alamat korespondensi:

Department of Biology, Faculty of Mathematics and natural Sciences, Cenderawasih University, Waena Campus, Jayapura-Papua Indonesia.

E-mail: hefmitanjung@yahoo.co.id located in Baliem Valley. The total area of Jayawijaya Regency is about $8,495 \mathrm{~km}^{2}$ which consists of 40 districts within this area distributed into 328 villages and four cities (Worabay, et al 2018). According to the health profile of this Regency (Ministry of Health of The Republic of Indonesia, 2016a) the total population was 267,334 people consisting of 140,669 men $(52.62 \%)$ and 
126,672 women $(47.38 \%)$ in which the male sex ratio compared to female was 1.11: 1 or every 111 men there are 100 women. Another important information gained was the productive ages ranged from 15-64 years corresponding to 206,353 people and while not productive from 0-14 years old were 58,764 people and non-productive 65-> 75 years as many as 2,217 people who were obtained by age group (Ministry of Health of The Republic of Indonesia, 2016a).

According to data observed, Malaria is one of the diseaseses still causing health problem in Indonesia to several certain degree. Parameter uses in Indonesia to observe malaria morbidity in an area called Annual Parasite Incidence (API). API value is the value of the number of positive cases of malaria per 1,000 population in one year. Although each region in Indonesia has a different API value, however from 2011-2015 its observed to continue decline, indicates that the government's success in controlling malaria cases. According to the report, in 2015 Papua was ranked highest for API, followed by West Papua, East Nusa Tenggara (NTT), Maluku, North Maluku and so on. Therefore, Papua, was pointed as the most affected Malaria Province among all provinces in Indonesia (Ministry of Health of The Republic of Indonesia, 2016b).

One of the determinants of the difficulty in overcoming malaria is due to the easy mutation of the $P$. falciparum gene (recombination) to form new, more surviving variations, namely the emergence of variations of $P$. falciparum that are resistant to antibiotics. Resistance is directly proportional to the increased risk of being infected by an individual (Sumari et al., 2010). Mutations that occur in genes that encode these proteins are considered responsible for the various invasion and resistance abilities developed by $P$. falciparum. Many previous research results have used merozoite surface protein (MSP) polymorphism as a genetic marker to see the genetic diversity of $P$. falciparum (Kiwamuka et al., 2009).

Low efficacy and treatment failure in tropical malaria caused by $P$. falciparum is a parasite that is resistant to antimalarial drugs or new infections. To differentiate the causes of treatment failure, $P$. falciparum genetic markers are used, the merozoit surface protein I and 2 (MSP1-MSP2) and glutamate rich protein (GLURP) genes. MSP1 and MSP2 are also proteins that can cause immune responses in humans and are important candidates in the development of malaria vaccines in the erythrocyte stage (Handayani et al., 2011).

The genotypic and phenotypic diversity of malaria parasites increases the ability to neutralize control measures such as therapeutic drugs. Sexual reproduction involving malaria parasites of different genotypes, which can occur when mosquitoes suck the blood of humans infected with various parasitic strains or when the same mosquito sucks the blood of more than one human that contains different parasitic genotypes, supports genetic recombination and results in greater diversity (Soe et al., 2017). Gardner et al. (2002) found that the P. falciparum genome is composed of 22.8 Mega bases spread over 14 chromosomes with a size of 0.643-3.29 Mega. The $\mathrm{A}+\mathrm{T}$ content is $80.6 \%$ and has at least 5,300 protein-coding genes.

MSP2 is a glycoprotein expressed on the surface of merozoites that have been considered candidates for malaria vaccine. The MSP2 gene has two main allelic families, FC27 and 3D7 / IC based on length and sequence variations in the central region. Block 3 of MSP2 is the most polymorphic and can function alone in describing the diversity of parasitic populations. P. falciparum parasitic populations are often characterized by wide genetic diversity in areas with high transmission intensity. Therefore, investigating the diversity of $P$. falciparum can be useful to describe the level of malaria transmission (Muhammed et al., 202).

So far there have been no research reports on the genetic diversity of $P$. falciparum in the highlands of Papua. Research that has been carried out by Sorontou \& Pakpahan (2015) is limited to coastal areas and lowlands. These reasons became the background of research on the genetic diversity of MSP2 P. falciparum clinical isolates in Wamena District Hospital. 


\section{MATERIALS AND METHODS}

This research used descriptive laboratory method with cross sectional approach. This research was carried out from March 2018 until February 2019. Sampling was carried out at Wamena Regional Hospital and the isolation process, Polymerase Chain Reaction (PCR), electrophoresis of research samples was set up at the genetics science laboratory in West Jakarta, Indonesia. The study population was all tropical malaria sufferers who went to Wamena Regional Hospital. Blood specimens were taken from patients diagnosed with tropical malaria by doctors based on microscopic examination results and had not received anti-malaria drug treatment. The sample studied was patients who met the inclusion and exclusion criteria. Inclusion criteria: (1) single $P$. falciparum infection with asexual stage parasite density $>1,000$ parasites $/ \mu 1$ or $>3+(1-10$ $\mathrm{P} / \mathrm{Lp}$ ), (2) willing to be a respondent, (3) signing informed consensus while exclusion criteria include: (1) people with tropical malaria who have received malaria therapy, (2) children under 12 years years old, (3) people severe rom malaria, (4) mixed infections and (5) there are other diseases that cause fever.

The sample was characterized as research subjects if the blood examination shows positive results. It recognized based on the results of thin and thick peripheral blood smear (HDT) preparations (Gold Standard) by a parasitologist and have been diagnosed by a specialist in internal medicine, as well as fulfilling the inclusion and exclusion criteria. Before the blood of a patient was drawn, the researchers need to provide an information for the patient and asked or their willingness to sign up the medical action consent form. After that the blood is taken for about $2 \mathrm{cc}$ to make blood preparations.

\section{DNA Isolation and Amplification}

The initial stage of MSP2 gene analysis is carried out by isolating the deoxyribonucleic acid (DNA) of the P. falciparum genome. The DNA of the $P$. falciparum genome was isolated using a kit called the genomic DNA mini kit (blood/ cultured cell). DNA amplification was carried out in two stages (nested), namely: 1) the first PCR, for amplification of the P. falciparum parasitic MSP2 gene using a specific pair of primers. Each mixture contains $2.5 \mu \mathrm{l}$ of DNA extracted as a template. Added to $22.5 \mu \mathrm{l}$ PCR reaction consisting of: 0.2 mM dNTP 1x PCR buffer with $1.5 \mathrm{mM} \mathrm{MgCL2}$ 1.25 units of Taq DNA polymerase (promega), and $2 \mathrm{mg} / \mu \mathrm{l}$ primary oligonucleotide specific genera (universal primers) namely:

P forward ( 5'- ATG AAG GTA ATT AAA ACA TTG TCT ATT ATA -3')

$P$ reverse $\left(5^{\prime}\right.$ - CTT TGT TAC CAT CGG TAC ATT CTT $\left.-3^{\prime}\right)$

(Atroosh et al., 2011)

The second amplification was carried out using a Thermal Cycler PCR machine. A mixture of $20 \mu 1$ (printed DNA as much as $2 \mu \mathrm{l}$, foward Primer $1 \mu \mathrm{l}$, Reverse Primer $1 \mu \mathrm{l}$, Enzym Polymerase $10 \mu \mathrm{l}$ and Deion $6 \mu \mathrm{l}$ ) was amplified by 30 cycles under the following conditions: predenaturation at $94^{\circ} \mathrm{C}$ for 30 seconds and $72^{\circ} \mathrm{C}$ for 15 seconds and ending with $72^{\circ} \mathrm{C}$ for 30 seconds five minutes. 2) The second PCR (nested PCR), to multiply the amplified DNA in the first PCR so that it can be visualized. The amplified DNA product on the first PCR was re-amplified using a specific primer to see the allele variation on MSP2, where the primers used were:

MSP-2M2-FCF 5'-AAT ACT AAG AGT GTA GGT GCA RAT GCT CCA-3',

MSP-2M2-FCR 5'-TTT TAT TTG GTG CAT TGC CAG AAC TTG AAC-3',

MSP-2M2-ICF 5'-AGA AGT ATG GCA GAA AGT AAK CCT YCT ACT-3',

MSP-2M2-ICR 5'- GAT TGT AAT TCG GGG GAT TCA GTT TGT TCG-3' (Atroosh et al, 2011).

\section{DNA Visualization (Electrophoresis)}

The quality of DNA amplification by PCR technique was seen using $1 \%$ agarose gel electrophoresis technique with a composition of 1 gram agarose gel powder with $100 \mathrm{ml}$ TBE1 $\times$ then the mixture was boiled in a heater for 25 minutes at $\pm 80{ }^{\circ} \mathrm{C}$. The mixture is left until the temperature drops to $55{ }^{\circ} \mathrm{C}$, and add red gel to agarose gel 
Table 1. Demographic data of positive patients infected with P. falciparum in Wamena District Hospital.

\begin{tabular}{|c|c|c|c|c|c|c|}
\hline No & Patients codes & Sex & Age & No. of Parasites & FC27 (bp) & 3D7/ IC (bp) \\
\hline 1. & M001 & $\mathrm{M}$ & 25 & $4+$ & 300 & 550 \\
\hline 2. & M002 & M & 25 & $3+$ & $350-600$ & $400-600$ \\
\hline 3. & M003 & $\mathrm{F}$ & 19 & $3+$ & $350-650$ & $500-600$ \\
\hline 4. & M004 & $\mathrm{F}$ & 19 & $3+$ & $350-650$ & $600-650$ \\
\hline 5. & M005 & M & 25 & $3+$ & $350-650$ & $450-600$ \\
\hline 6. & M006 & M & 12 & $3+$ & $400-700$ & $\mathrm{~N}$ \\
\hline 7. & M007 & M & 20 & $3+$ & 400 & $\mathrm{~N}$ \\
\hline 8. & M008 & M & 18 & $3+$ & $350-750$ & 350 \\
\hline 9. & M009 & M & 20 & $3+$ & 350 & 750 \\
\hline 10. & M010 & $\mathrm{F}$ & 26 & $3+$ & 350 & $500-600$ \\
\hline 11. & M011 & $\mathrm{F}$ & 19 & $3+$ & $350-700$ & $600-700$ \\
\hline 12. & M012 & M & 19 & $3+$ & 400 & 800 \\
\hline 13. & M013 & M & 14 & $4+$ & $350-600$ & 500 \\
\hline 14. & M014 & M & 22 & $4+$ & $600-700$ & 600 \\
\hline 15. & M015 & $\mathrm{F}$ & 26 & $3+$ & 750 & 700 \\
\hline 16. & M016 & $\mathrm{F}$ & 34 & $3+$ & 700 & $450-550$ \\
\hline 17. & M017 & $\mathrm{F}$ & 23 & $4+$ & 700 & $400-600$ \\
\hline 18. & M018 & M & 20 & $3+$ & 700 & 500 \\
\hline 19. & M019 & $\mathrm{F}$ & 18 & $3+$ & 700 & 600 \\
\hline 20. & M020 & $\mathrm{F}$ & 25 & $4+$ & $400-750$ & $\mathrm{~N}$ \\
\hline 21. & M021 & $\mathrm{F}$ & 20 & $3+$ & $\mathrm{N}$ & $\mathrm{N}$ \\
\hline 22. & M022 & $\mathrm{M}$ & 22 & $3+$ & $350-500$ & $300-350$ \\
\hline 23. & M023 & $\mathrm{F}$ & 20 & $3+$ & $650-750$ & $550-700$ \\
\hline 24. & M024 & $\mathrm{F}$ & 23 & $3+$ & 700 & 500 \\
\hline 25. & M025 & $\mathrm{M}$ & 26 & $4+$ & $350-700$ & 550 \\
\hline 26. & M026 & M & 28 & $3+$ & $800-850$ & 850 \\
\hline
\end{tabular}

Note: $\mathrm{N}=$ no (no line observed).

(Triajayanti, 2018). Electrophoresis was carried out in an electrophoretic apparatus (Horizontal MiniSub DNA Biorad) containing 1x TBE (TrisBoric acid and 0.5 M EDTA pH 8.0) and added $0.1 \%$ Ethidium Bromide intercalator. The DNA of PCR as much as $5 \mu$ l loading dye $(0.25 \%$ bromphenol blue, $40 \% \mathrm{w} / \mathrm{v}$ sucrose), was then inserted into the wells contained in the gel. As a marker of the size of DNA bands electrophoresis results in Marker gel (100 bpDNA ladder Cat no: 15628-019 LOT No. 1289697 as much as $3 \mu \mathrm{g} / \mu \mathrm{l}$; promega) mixed with $2 \mu \mathrm{l}$ loading dye and $4.5 \mu \mathrm{l}$ $1 x$ TBE buffer. Gel electrophoresis at 110 volt electricity for 40 minutes. Furthermore it was detected using Gel Doc 1000 (Biorad USA) to be visualized with ultraviolet light at a wavelength of $300 \mathrm{~nm}$ and recorded.

\section{RESULTS AND DISCUSSION}

\section{Result}

Demographic data of 26 positive P. falciparum blood isolates from clinical samples taken from Wamena District Hospital can be seen in Table 1. From the data of 26 samples of positive patients infected with $P$. falciparum in RSUD Wamena based on the number of male sex is $65.4 \%(17 / 26)$ while the female sex is $34.6 \%(9 / 26)$. The data obtained based on productive age (15-65 years) is $92.3 \%(24 / 26)$ and the age of unproductive (0-14 years) is $7.7 \%(2 / 26)$ and there is no samples of non-productive age (65 - >75 years).

The results of DNA isolation from 26 positive $P$. falciparum clinical were 22 samples containing the MSP2 gene $(84.6 \%)$. The banding pattern that appears can be seen in fragments 1-9, 11-19, 23-26 which show a clear and bright band pattern on the 
Table 2. Profile of distribution allele gene MSP2.

\begin{tabular}{lllcc}
$\begin{array}{l}\text { Gene } \\
\text { MSP2 }\end{array}$ & Allele & Ratio & $\%$ & $\begin{array}{c}\text { Amplification } \\
\text { (bp) }\end{array}$ \\
\hline & FC27 & $25 / 26$ & 96,2 & $300-850$ \\
& 3D7/IC & $22 / 26$ & 84,6 & $300-850$ \\
& FC27 + 3D7/IC & $22 / 26$ & 84,6 & $300-850$ \\
\hline
\end{tabular}

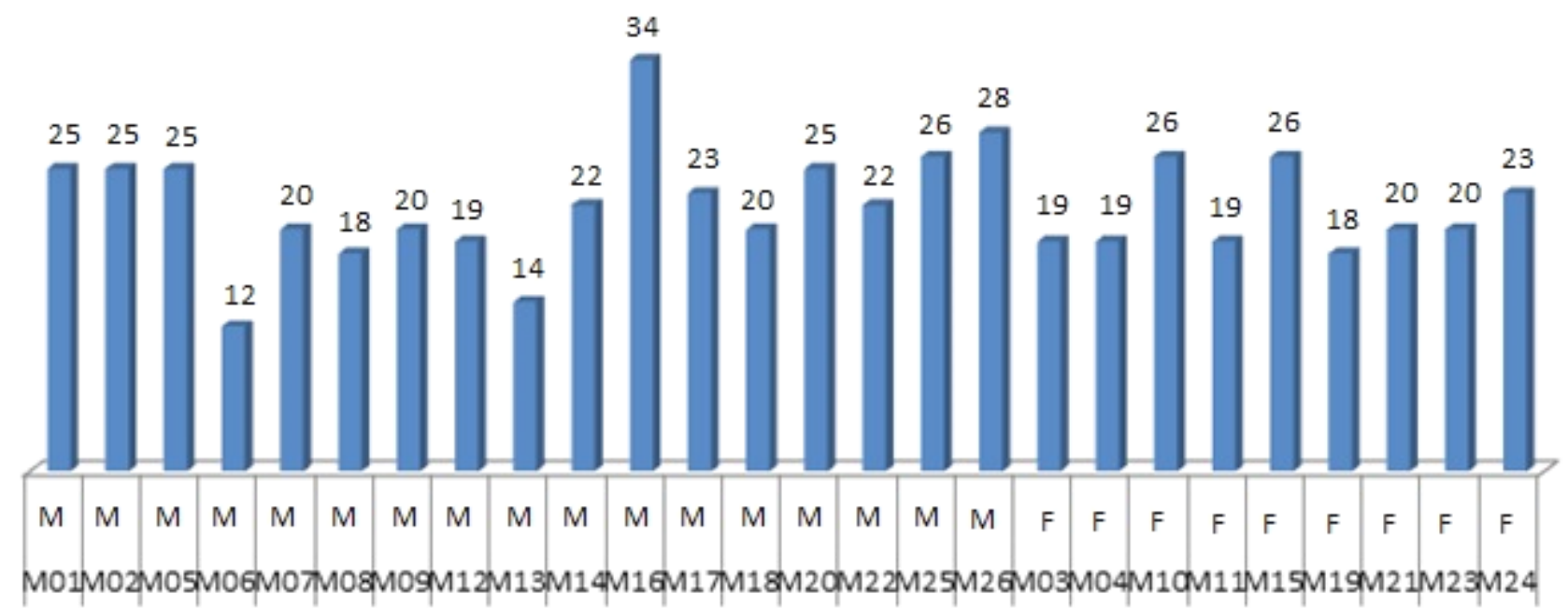

Figure 1. The demographic data of patients infected with P. falciparum positive in Wamena General Hospital by sex and age in 2018.

MSP2 gene. PCR results of the MSP2 gene of $P$. falciparum can be seen in Figure 2.

The allele family of the MSP2 gene from the $P$. falciparum were 2 alleles, namely 3D7 / IC and FC27 and a combination of both alleles (dialel), a single allele and a combination of two MSP2 alleles are at 3D7 / IC alleles $84.6 \%(22 / 26)$ and FC27 96.1\% (25/26) and the mixed alleles between the two alleles namely 3D7 / IC and FC27 were $84.6 \%(22 / 26)$. The existence of alleles can be seen from the results of electrophoresis in Figure 2.

Total 26 samples of $P$. falciparum clinical isolates in Wamena District Hospital with the highest distribution of MSP2 genes in FC27 alleles were 25 samples $(96.2 \%)$; 3D7 / IC alleles were 22 samples $(84.6 \%)$ while the mix of the two alleles were 22 samples $(84.6 \%)$. Amplification of a single allele and mix of alleles with sizes 300-850 bp. Distribution of $P$. falciparum MSP2 gene alleles can be seen in table 2 .
Among the 26 clinical samples of $P$. falciparum isolates in RSUD Wamena, there were $77.3 \%$ male and $41 \%$ female samples. FC27 alleles in men $100 \%$ (17/17), female 88.9\% (8/9) and 3D7 / IC alleles in men $82.4 \%$ (14/17), women $88.9 \%(8 / 9)$ whereas the mix of the two alleles in men was $82.4 \%$ $(14 / 17)$, women were $88.9 \%(8 / 9)$. The results of identifying MSP2 P. falciparum gene alleles by sex can be seen in table 3 .

The results of identification of $P$. falciparum clinical isolates in Wamena District Hospital with 26 samples were found with the most cases at productive age, namely ages between 15-34 years with a single allele $95.8 \%$ for 23 cases and a mixture of both alleles $87.5 \%$ for 21 cases, in the case of unproductive age ie 12 and 14 years old with a single allele of $100 \%$ (FC27) of 2 cases; $50 \%$ (3D7 / IC) in one case; a mixture of both $50 \%$ alleles in one case and no sample at non productive age (Table 3 ). 

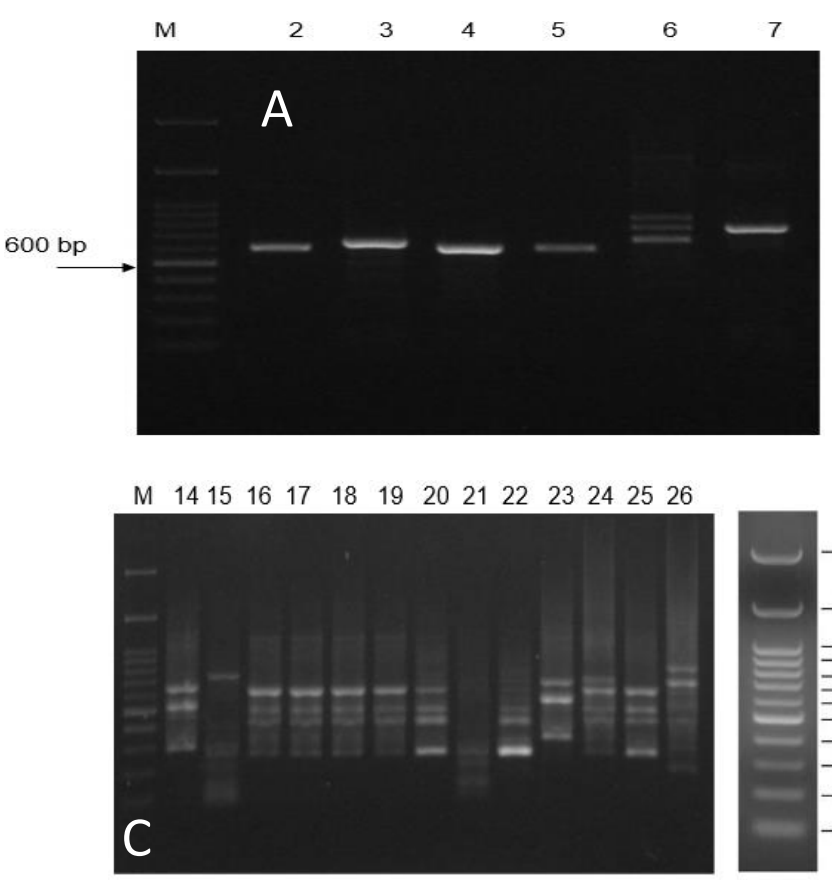

Unit : bp

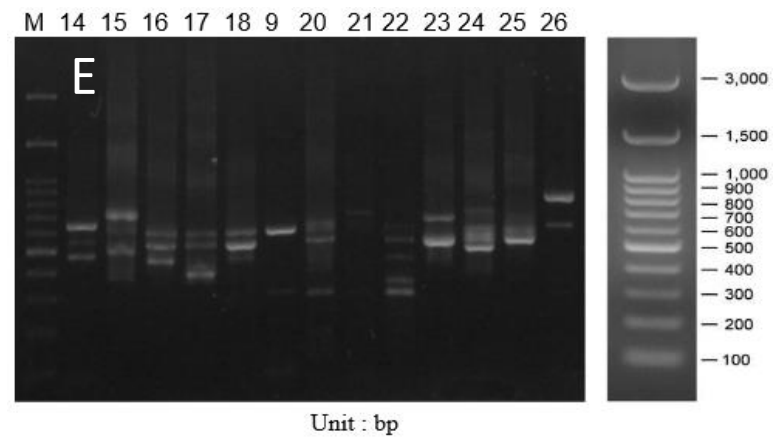

$\begin{array}{lllllllllllllll}M & 1 & 2 & 3 & 4 & 5 & 6 & 7 & 8 & 9 & 10 & 11 & 12 & 13\end{array}$
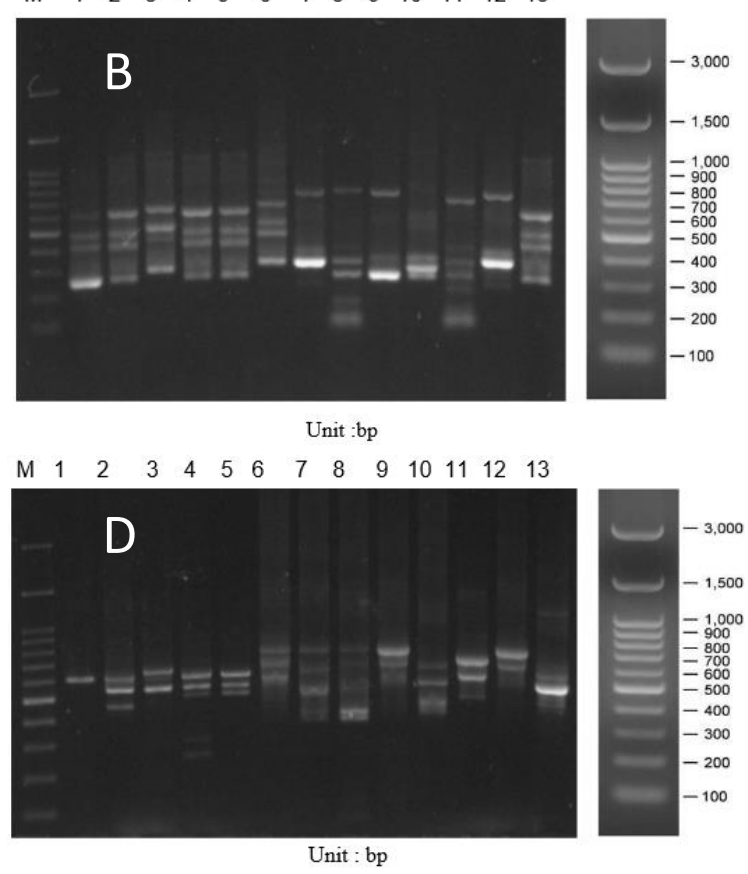

Figure 2. Amplification results of gene MSP2 from affected malarian. M: Marker A. Lane 2-7: gen MSP2; B. Results of nested PCR allele FC27 Lane 1-13: allele FC27; C. Results nested PCR allele FC27, Lane 14-26: allele FC27; D. Results nested PCR allele 3D7/IC MSP2. Lane 1-13: allele FC27; E. Results nested PCR alel 3D7/IC MSP2. Lane 14-26: alel FC27.

\section{Discussion}

Based on demographic data it was found that the number of cases according to male was higher corresponding to $65.4 \%(17 / 26)$ while women $34.6 \%(9 / 26)$, especially for productive ages between 15-34 years. The results of this study conducted are similar to the data obtained from the health profile of Jayawijaya Regency (Misnistry of Healt of The Republic of Indonesia, 2016a) in which the malaria morbidity rate based on malaria-positive blood supply according to sex shows that men were found in 393 cases while women were 277 cases.

Malaria at an altitude of 1500 meters is found rarely and usually unstable when it occurs. To confirm reports of a recent increase in stable malaria transmission in the Oksibil Valley, at an altitude of 1,250-1500 meters in the Jayawijaya Mountains in Papua, Indonesia, 5 malariometric surveys were conducted in 4 villages between May 1990 and July 1991 A total of 3380 blood smears from 1949 people were examined. 
Prevalence rates throughout the survey period were consistent in each of the 4 villages, with an average of $10 \%$ for infants, $50 \%$ for children aged 1-4 years, 35\% for those aged 5-9 years, $28 \%$ for those who 10-14 years, and 16\% for adults (over 15 years) coincides with the replacement of traditional village huts with more modern social housing. This replacement requires the construction of extensive drainage ditches, which inadvertently also function as vector developers (Anthony et al., 1992).

A total of 26 samples were tested and analyzed descriptively. The results of the analysis of the presence of the MSP2 gene showed that FC27 single allele was more dominant, $96.2 \%$ than the 3D7/IC allele, $84.6 \%$. Similar results obtained from studies conducted in Indonesia (Aceh Province), Thailand, Central Sudan, and South Benin show the results of the identification of the dominant FC27 allele from 3D7/IC (Snounou et al., 1999; Hamid et al., 2013; Ogouyemi et al., 2013; Jamil et al., 2018).

Different research results obtained in Thailand namely Tak, Kanchanaburi and Ranong Provinces show different results that the single allele 3D7/IC is more dominant than FC27 (Congpuong et al., 2014) Likewise in Iran, Ivory Coast (West Africa), Gabon (Central Africa), Tanzania, southern Brazzaville (Republic of the Congo), sub-Saharan Africa, Sudan, Haiti, Burkina Faso, Pawe (North West Ethiopia), Pahang (Malaysia), and Pakistan based on the analysis identified 3D7/IC allele frequencies are higher and more common than FC27 (Zakeri et al., 2005; Heidari et al., 2007;
Ganchi et al., 2010; Mwingira et al., 2011; Meyengue et al., 2011; Londono et al., 2012; Kidima et al., 2015; Yavo et al., 2016; Mustaf et al., 2017; Some et al., 2018).

Mixed infections with the presence of both MSP2 alleles namely 3D7 / IC and FC27 in this study were high $(84.6 \%)$. The results of this study show similarities with studies conducted in Myanmar and Osogbo (Nigeria) where mixed infections are high in both alleles (Kang et al., 2010; Ojurongbe., 2011).

Distribution of MSP2 gene alleles at the age of unproductive age of 12 and 14 years with 100\% single allele (FC27) in 2 cases; 50\% (3D7 / IC) in 1 case; mix both $50 \%$ alleles in 1 case. These results are in line with the results of the study of Koukouikila et al. (2012) about the prevalence of asymptomatic P. falciparum infection evaluated in a group of children living in Brazzaville found that the MSP2 gene allele family was for 457 / IC alleles 45\% (23/51) and FC27 35\% (18/51) while for both alleles (3D7/IC and FC27) are 14\% (7/51). However, the dominance between the two alleles in children can be alternated according to location as shown by the results of Soulama et al. (2009) in the city of Nanoro, Burkina Faso in Africa from the identification of MSP2 alleles, FC27 type alleles are more frequent in rural children, compared with those who live in urban areas. 3D7 type alleles are more common in cases of symptomatic malaria in urban areas compared to those from rural areas.

Research at Grande Comore found that the dominant type of allele of the MSP2 gene in isolates from the 2006-2007 group was 3D7 (90.8\%)

Table 3. Identification of $P$. falciparum allele gene MSP2 based on sex and age ranges.

\begin{tabular}{|c|c|c|c|c|c|}
\hline \multirow[b]{2}{*}{ Allele } & \multicolumn{2}{|c|}{ Sex } & \multicolumn{3}{|c|}{ Age } \\
\hline & Male & Female & $\begin{array}{c}0 \text { - } 14 \text { Years } \\
\text { (Non productive } \\
\text { ages) }\end{array}$ & $\begin{array}{c}15 \text { - } 65 \text { Years } \\
\text { (Productive } \\
\text { ages) }\end{array}$ & $\begin{array}{c}65->75 \text { Years } \\
\text { (Non productive } \\
\text { ages) }\end{array}$ \\
\hline Allele FC27 & $\begin{array}{l}100 \% \\
(17 / 17)\end{array}$ & $\begin{array}{l}88,9 \% \\
(8 / 9)\end{array}$ & $\begin{array}{l}100 \% \\
(2 / 2)\end{array}$ & $\begin{array}{l}95,8 \% \\
(23 / 24)\end{array}$ & 0 \\
\hline Allele 3D7/IC & $\begin{array}{l}82,4 \% \\
(14 / 17)\end{array}$ & $\begin{array}{l}88,9 \% \\
(8 / 9)\end{array}$ & $\begin{array}{l}50 \% \\
(1 / 2)\end{array}$ & $\begin{array}{l}95,8 \% \\
(23 / 24)\end{array}$ & 0 \\
\hline $\begin{array}{l}\text { Mixed FC27 AND } \\
\text { 3D7/IC }\end{array}$ & $\begin{array}{l}82,4 \% \\
(14 / 17)\end{array}$ & $\begin{array}{l}88,9 \% \\
(8 / 9)\end{array}$ & $\begin{array}{l}50 \% \\
(1 / 2)\end{array}$ & $\begin{array}{l}87,5 \% \\
(21 / 24)\end{array}$ & 0 \\
\hline
\end{tabular}


while the most common isolate of the 2013-2016 group was the FC27 allele (91.1\%) (Huang et al.,2018). The distribution of MSP2 gene alleles from samples with male sex was $77.3 \%$ and $41 \%$ female obtained FC27 alleles in 100\% (17/17) men, $88.9 \%(8 / 9)$ women and 3D7 alleles / IC in men $82.4 \%(14 / 17)$, women $88.9 \%(8 / 9)$ while the mix of the two alleles in men $82.4 \%(14 / 17)$, women $88.9 \%(8 / 9)$. These results indicate that allele dominance is only found in male sethat is FC27 allele is more dominant than 3D7/IC and mixed alleles, whereas in women there is no allele dominance.

Research carried out in the highlands of Papua included studies of malaria strains in the Oksibil valley to determine the MSP2 gene sequence at one location at different times where the variation of the MSP2 gene was found to change over time but in general, the MSP2 allele repertoire was Circulating changes with time caused during infection, patients make a strain-specific antibody response to MSP2 from the infecting strain and this has an inhibitory effect on parasitic growth (Eisen et al., 1998).

Based on the results obtained in this study qualitatively can be identified that there is a relationship between sex and age to the presence of 3D7/IC and FC27 alleles, but quantitatively there is no relationship as stated by Sorontou and Pakpahan, (2015) concludes that both MSP2 alleles ie 3D7/IC and FC27 from $P$. falciparum did not show a significant correlation with parasitic density, age and sex in Jayapura City, Papua Province, Indonesia.

The results of these studies show that genetic diversity of $P$. falciparum isolates is caused by variants of parasitic forms in different geographical regions, and occultism of several genotypes during a single mosquito, is one of the main obstacles in the design of malaria vaccines (Heidari et al., 2007; Raj et al., 2004; Moore et al., 2002. Genetic diversity is also caused by transmission of drug-resistant $P$. falciparum, so it is important to consider the level of entomological inoculation and careful monitoring of drug resistance which is very important for malaria control strategies (Zakeri et al., 2005). Besides malaria population varies according to the intensity of transmission in malaria endemic areas so that in hyperendemic areas higher than low endemicity areas, this can also be caused by human migration events that play a role in increasing changes in malaria parasite populations (Mohammed et al., 2017).

One limitation of developing a malaria vaccine is the wide genetic diversity in the parasitic population which limits the efficacy of the acquired immune protection against malaria. Individuals are often simultaneously infected by several parasitic clones that are related to the intensity of transmission and are described as factors that determine the host's immune status. This situation might have an impact on the effectiveness of malaria vaccines and the clinical problems of the disease. It is therefore important to characterize parasitic populations to adjust malaria control and elimination strategies (Yavo et al., 2016). An earlier case-control study in Papua New Guinea showed that infection with type MSP2 FC27 was potentially a vaccine rather than type 3D7 (Genton et al., 2002).

\section{CONSLUSSION}

The results of this study showed that the alleles at the MSP2 gene locus from clinic isolates in Wamena with size range 300-850 bp consist of two allele classes, FC27 and 3D7/IC.

\section{ACKNOWLEDGEMENT}

We would like to express our gratitude to Mr. Felly G. Sahureka, dr., M.Kes., Sp.PK the Head of Hospital and staffs of Laboratory of Regional Hospital of Jayawijaya Regency who have helped the researhers during the samples collection. Our thanks also go to Mr. Hamid and staffs of Health Laboratory of Provincial Health Laboratory who have helped us storing the samples. We also thank the Laboratory of Genetic Science who have helped the analysis process of biomollecular. All research was funded by Grant of the Ministry of 
Research, Technology and Higher Education Indonesia.

\section{REFERENCES}

Atroosh, W.M., H.M. Al-Mekhlafi., M.A.K. Mahdy., R. SaifAli., A.M. Al-Mekhlafi, and J. Surin. 2011. Genetik diversity of Plasmodium falciparum isolates from Pahang, Malaysia based on MSP-1 and MSP-2 genes. Parasites $\mathcal{E}$ Vector. 4: 233.

Anthony, R.L., M.J. Bangs., N. Hamzah., H. Basri., Purnomo, and B. Subianto. 1992. Heightened transmissions of stable malaria in an isolated population in the highlands of irian Jaya, Indonesia. Am J Trop Med Hyg. 47(3): 346356.

Congpuong, K., R. Sukaram., Y. Prompan, and A. Dornae. 2014. Genetic diversity of the msp-1, msp-2, and glurp genes of Plasmodium falciparum isolates along the ThaiMyanmar borders. Asian Pacific Journal of Tropical Biomedicine. 4(8): 598-602.

Eisen, D., H. Billman-Jacobe., V.F. Marshall, D. Fryauff, and R.L. Coppel. 1998. Temporal variation of the merozoite surface protein-2 gene of Plasmodium falciparum. Infect Immun. 66(1): 239.

Gardner, M.J., N. Hall., E. Fung., O. White., M. Berriman., R.W. Hyman., J.M. Carlton., A. Pain., K.E. Nelson., S. Bowman., I.T. Paulsen., K. James., J.A. Eisen., K. Rutherford., S.L. Salzberg., A. Craig., S. Kyes., M.S. Chan., V. Nene., S.J. Shallom., B. Suh., J. Peterson., S. Angiuoli., M. Pertea., J. Allen., J. Selengut., D. Haft., M.W. Mather., A.B. Vaidya., D.M. Martin., A.H. Fairlamb., M.J. Fraunholz., D.S. Roos., S.A. Ralph., G.I. McFadden., L.M. Cummings., G.M. Subramanian., C. Mungall., J.C. Venter., D.J. Carucci., S.L. Hoffman., C. Newbold., R.W. Davis., C.M. Fraser, and B.N. Barrell. 2002. Genome sequence of the human malaria parasite Plasmodium falciparum. Nature. 419(6906): 498-511.

Genton, B., I. Betuela., I. Felger., F. Al-Yaman., R.F. Anders., A. Sau., L. Rare., M. Baisor., K. Lorry., G.V. Brown., D. Pye., D.O. Irving., T.A. Smith., H.P. Beck, and M.P. Alpers. 2002. A recombinant blood-stage malaria vaccine reduces Plasmodium falciparum density and exerts selective pressure on parasite populations in a phase 1-2b trial in Papua New Guinea. J Infect Dis. 15: 185(6): 820-7.

Ghanchi, N.K., A. Martensson., J. Ursing., S Jafri S., S Bereczky., R. Hussain, and M.A. Beq. 2010. Genetic diversity among Plasmodium falciparum field isolates in Pakistan measured with PCR genotyping of the merozoite surface protein 1 and 2. Malaria Journal. 1: 9.

Hamid, M.M.A., S.B. Mohammed, and I.M.E. Hassan. 2013. Genetic diversity of Plasmodium falciparum field isolates in central Sudan inferred by PCR genotyping of merozoite surface protein 1 and 2. N. Am J Med Sci. 5(2):95-101.
Handayani, S., E. Salwati, and E. Tjitra. 2011. Genetic diversity of $P$. falciparum markers from Dihidroartemisinin-Piperakuin monitoring research specimens in Kalimantan and Sulawesi. Media Litbang Kesehatan. 22(3): 120-130.

Heidari, A., H. Keshavarz., M.B. Rokni, and T. Jelinek. 2007. Genetic diversity in merozoite surface protein(MSP)-1 and MSP-2 genes of Plasmodium falciparum in a major endemic region of Iran. Korean J Parasitol. Mar. 45(1): 5963.

Huang, B., F. Tuo., Y. Liang., W. Wu., G. Wu., S. Huang., Q. Zhong., X. Su., H. Zhang., M. Li., A. Bacar., K. S. Abdallah., A.M.S.A Mliva., Q. Wang., Z. Yang., S. Zheng., Q. Xu., J. Song, and C. Deng. 2018. Temporal changes in genetic diversity of MSP1, MSP2, and MSP3 in Plasmodium falciparum isolates from Grande Comore Island after introduction of ACT. Malaria Journal. 17: 83. doi: 10.1186/s12936-018-2227-3.

Jamil, K.F., S. Supargiyono., Syafruddin., N. Pratama, and S. Silvy. 2018. Genetic diversity of merozoite surface protein-2 in Plasmodium falciparum isolates from Aceh province, Indonesia. IOP Conference Series Earth and Environmental Science. 125(1): 012036.

Kang, M.K., S.U. Moon., J.Y. Kim., S.H. Cho., K. Lin., W.M. Sohn., T.S. Kim, and B.K. Na. 2010. Genetic polymorphism of merozoite surface protein-1 and merozoite surface protein-2 in Plasmodium falciparum field isolates from Myanmar. Malaria Jounal. 9: 131. https://doi.org/10.1186/1475-2875-9-131.

Kidima, W., and G. Nkwengulila. 2015. Plasmodium falciparum MSP2 Genotypes and multiplicity of infections among children under five years with uncomplicated malaria in Kibaha, Tanzania. Journal of Parasitology Research. (1): 1-6.

Kiwanuka., G.N. 2009. Genetic diversity in Plasmodium falciparum merozoite surface protein 1 and 2 coding genes and its implications in malaria epidemiology: a review of published studies from 1997-2007. Journal Vector Borne Dis. 46(1): 1-12.

Koukouikila, K.F., V. Malonga., P.I. Mayengue., M. Ndounga., C.J. Vouvoungui, and F. Ntoumi. 2012. Genetic polymorphism of merozoite surface protein 2 and prevalence of K76T pfort mutation in Plasmodium falciparum field isolates from Congolese children with asymptomatic infections. Malaria Journal. 11: 105.

Londono, R.B., T.P. Eisele., J. Keating., A. Bennett, and D.J. Krogstad. 2012. Genetic diversity in the merozoite surface protein 1 and 2 genes of Plasmodium falciparum from the Artibonite Valley of Haiti. Acta Trop. 121(1): 612.

Meyengue, P.S., M. Ndounga., C.J. Vouvoungui, and F. Ntoumi. 2011. Genetic polymorphism of merozoite surface protein-1 and merozoite surface protein- 2 in Plasmodium falciparum isolates from Brazzaville, Republic of Congo. Malaria Journal. 10: 276. https://doi.org/10.1186/1475-2875-10-276.

Ministry of Health of the Republic of Indonesia. 2016a. Jayawijaya Regency health profile. 
Ministry of Health of the Republic of Indonesia. 2016b. Health Profile of Papua Province in 2016.

Mohammed, H., M. Kassa., A. Assefa., M. Tadesse, and A. Kebede. 2017. Genetic polymorphism of merozoite surface protein-2 (MSP-2) in Plasmodium falciparum isolates from Pawe District, North West Ethiopia. PLoS One. 12(5): e0177559.

Moore, S.A., E.G.E. Surgey, and A.M. Cadwgan. 2002. Malaria vaccines: where are we and where are we going? Lancet Infect Dis. 2: 737-743.

Mustafa, S.O., M.M.A. Hamid., M.A. Aboud., M. Amin., M.S. Muneer., K. Yasin., N.S. Mahgoub, and N.M.E. Bagir. 2017. Genetic diversity and multiplicity of Plasmodium falciparum merozoite surface protein 2 in field isolates from Sudan. F1000Research. 6: 1790. https://doi.org/ 10.12688/f1000research.12585.1.

Mwingira, F., G. Nkwengulila., S. Schoepflin., D. Sumari., H. P. Beck., G. Snounou., I. Felger., P. Olliaro \& K. Mugittu. 2011. Plasmodium falciparum MSP1, MSP2 and glurp allele frequency and diversity in sub-Saharan Africa. Malaria Journal. 10: 79. doi: 10.1186/1475-2875-10-79.

Ogouyemi, H. A., D.K. Gazard., N. Ndam., E. Topanou., O Garba., P Elegbe., T. Hountohotegbe, and A. Massougbodji. 2013. Genetic polymorphism of merozoite surface protein-1 and merozoite surface protein-2 in Plasmodium falciparum isolates from children in South of Benin. Parasite. 20: 37.

Ojurongbe, O., B.A.F. Fagbenro., O.A. Adeyeba, and J.F. Kun. 2011. Allelic diversity of merozoite surface protein 2 gene of $P$. falciparum among children in Osogbo, Nigeria. West Indian Med J. 60(1): 19-23.

Raj, D.K., B.R. Das., A.P. Dash, and P.C. Supakar. 2004. Genetic diversity in the MSP1 gene of Plasmodium falciparum in different malaria endemic localities. Am J Trop Med Hyg. 71: 285-289.

Soe, T.N., Y. Wu., M.W. Tun., X. Xu., Y. Hu., Y. Ruan., A.Y.N. Win., M.H. Nyunt., N.C.N. Mon., K.T. Han., K.M. Aye., J. Morris., P. Su., Z. Yang., M.P. Kyaw, and L. Cui. 2017. Genetic diversity of Plasmodium falciparum populations in southheast and western Myanmar. Parasites $\mathcal{E}$ Vectors. 10: 322.

Snounou, G., X. Zhu., N. Siripoon., B. Jarra., S. Thaithong., K.N. Brown, and S. Viriyakosol. 1999. Biased distribution of MSP1 and MSP2 allelic variants in Plasmodium falciparum populations in Thailand. Trans $R$. Soc. Trop Med Hyg. 93(4): 369-374.

Some, A.F., T. Bazie., I. ZongoI., R.S. Yerbanga., F. Nikiema., C. Neya., L.K. Taho, and J.B. Ouedraogo. 2018. Plasmodium falciparum MSP1 and MSP2 genetic diversity and allele frequencies in parasites isolated from symptomatic malaria patients in Bobo-Dioulasso, Burkina Faso. Parasit Vectors. 11(1): 323. doi: 10.1186/s13071-018-2895-4.

Soulama, I., I. Nebie., A. Ouedraogo., A. Gansane., A. Diarra., A.B. Tiono., E.C. Bougouma., A.T. Konate., G.B. Kabre., W.R.J. Taylor, and S.B. Sirima. 2009. Plasmodium falciparum genotypes diversity in symptomatic malaria of children living in an urban and a rural setting in Burkina Faso. Malaria Journal. 8: 135.

Sorontou, Y \& A. Pakpahan. 2015. Frequency distribution of Plasmodium falciparum MSP-2 allele and associaton with clinical manifestations and demographic factors in Jayapura municipal, Papua Province, Indonesia. International Journal of Parasitology Research. 7(1): 143-151.

Sumari, D., K.M. Hosea., J.P. Mugasa, and S. Abdulla. 2010. Genetic diversity of Plasmodium falciparum strains in children under Five Years of Age in Southeastern Tanzania. The Open Tropical Medicine Juournal. 3(1): 1014.

Triajayanti, A. 2018. Variasi genetik gen Plasmodium falciparum merozoit surface protein-1 (Pfmsp-1) dari penderita malaria di wilayah kerja Puskesmas Hanura, Pesawaran, Lampung. Online access. Perpustakaan Universitas Lampung.

Worabay, M.G., B. Kiyai, and H.F. Kolondam. 2018. Local government policy in the construction of educational facilities and infrastructure in Jayawijaya Regency, Papua Province. Jurnal Administrasi Publik. 4(59): 10-20.

Yavo, W., A. Konate., D.P. Mawili-Mboumba., F.K. Kassi., M.L.T. Mbuyi., E.K. Angora., E.I.H. Menan., and M.K. Bouyou-Akotet. 2016. Genetic polymorphism of msp1 and msp2 in Plasmodium falciparum isolates from Côte d'Ivoire versus Gabon. Journal of Parasitology Research. Article ID 3074803. http://dx.doi.org/10.1155/ 2016/3074803.

Zakeri, S., S. Bereczky., P. Naimi., J.P. Gil., N.D. Djadid., A. Farnert., G. Snounou, and A. Bjorkman. 2005. Multiple genotypes of the merozoite surface proteins 1 and 2 in Plasmodium falciparum infections in a hypoendemic area in Iran. Trop Med Int Health. 10(10): 1060-1064. doi: 10.1111/j.1365-3156.2005.01477.x.

Zhang, D., L. Yao, and P. Bernd. 1994. Expression of Trk and neurotrophin mRNA in dorsal root and sympathetic ganglia of the quail during development. Journal of Neurobiology. 12(25): 1517-1532.

Zhou, X.F., and R.A Rush. 1991. Funcional roles of neurotrophin 3 in the developing and mature sympathetic nervous system. Moleculer Neurobiology. 13: 185-197. 